\title{
A Case of Malignant Lymphomas that Healed Completely After Oral Administrations of 4-Hydroxybenzaldehyde
}

\author{
Kimihiko Okazaki* \\ Okazaki Medical Clinic, Japan
}

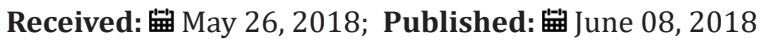

*Corresponding author: Kimihiko Okazaki, Okazaki Medical Clinic, Ukyoku Kyoto, Japan

\begin{abstract}
In 1969, Mutsuyuki Kochi [1,2] developed 4-Hydroxybenzaldehyde for use as a novel anti-tumor agent without side effect and acquired its patent. Accordingly, this medicine is capable of preventing carcinogenesis when used in sufficient quantity. To treat advanced cancers, an oncologist should start with giving the cancer patient a small dose of the 4-Hydroxybenzaldehyde to avoid the possible severe hemorrhage of a tumor caused by excessive necrosis. Therefore, it has useful applications in treating lymphomas and leukemia's. Consequently, those who have these diseases can receive a considerably large dose of the medicine. The mechanism of action of the medicine is apparently competitive inhibition of tyrosine kinase, which is the rate-limiting enzyme in the pathway of carcinogenesis $[3,4]$.
\end{abstract}

\section{Case Report}

\section{Case 1}

A 45-year-old woman (Y.Y.) visited the author's clinic on August 7,2014 . She said that she had been diagnosed to have a malignant lymphoma of $3 \mathrm{~cm}$-diameter at the right side of her clavicular cavity and another one of $1 \mathrm{~cm}$-diameter at the right side of her neck at Mitsuhashi Gynecological Clinic in Kohriyama City, Nara Prefecture on June 20, 2014. At the author's clinic, she was prescribed with daily $83 \mathrm{mg}(17 \mathrm{ml}$ of $5 \mathrm{mg} / \mathrm{ml}$ aqueous solution) of 4-Hydroxybenzaldehyde during the period from August 8, 2014 until December 8,2014 . The daily dose was raised to $111 \mathrm{mg}(22 \mathrm{ml}$ of $5 \mathrm{mg} / \mathrm{ml}$ aqueous solution) during the period from December 9, 2014 until March 8, 2015. The daily dose was raised to $167 \mathrm{mg}$ ( $33 \mathrm{ml}$ of $5 \mathrm{mg} / \mathrm{ml}$ aqueous solution) during the period from March 9, 2015 to May 13, 2015. The daily dose was raised to 222mg (44ml of $5 \mathrm{mg} / \mathrm{ml}$ aqueous solution) during the period from May 14, 2015 to August 11, 2015. The daily dose was raised to $333 \mathrm{mg}(67 \mathrm{ml}$ of $5 \mathrm{mg} / \mathrm{ml}$ aqueous solution) during the period from August 12, 2015 to September 13,2015 . The daily dose was raised to $500 \mathrm{mg}(100 \mathrm{ml}$ of $5 \mathrm{mg} / \mathrm{ml}$ aqueous solution) during the period from September 14, 2015 until June 4, 2016. By the end of the above period, both of her tumors have vanished. Her oral intake of the medicine was ceased accordingly. As of May 25, 2018, no sign of recurrence was observed.

\section{References}

1. Kochi M (1985) Antitumor activity of benzaldehyde derivative. Cancer Treatment Reports 69(5): 533-537.

2. Kochi M (1969) Manufacturing Process of Anticancer Substance. Japanese Patent No. 560349.

3. Okamoto K, Okamoto I, Okamoto W, Tanaka K, Takezawa K, et al. (2010) Role of surviving in EGFR inhibitor-induced apoptosis in non-small cell lung cancers positive for EGFR Mutations. Cancer Research 70(24): 10402-10410.

4. Okada M, Nakagawa H (1989) A Protein Tyrosine Kinase Involved in Regulation of Pp 60 Function. J Biol Chem 264(35): 20886-20893. 
This work is licensed under Creative Commons Attribution 4.0 License

To Submit Your Article Click Here:

Submit Article

DOI: 10.32474/OAJOM.2018.01.000124

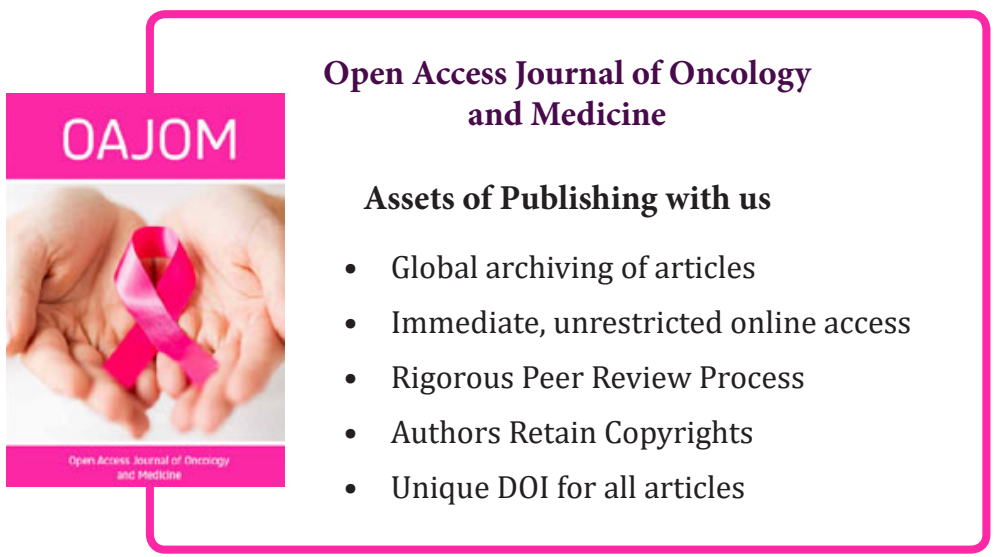

